\title{
A SIMULATION APPROACH TO RECONCILING CUSTOMS AND TRADE RISK ASSOCIATED WITH CROSS-BORDER FREIGHT MOVEMENTS
}

\author{
A.J. Hoffman ${ }^{1 *}$, S. Grater ${ }^{2}$, A. Schaap ${ }^{2}$, J. Maree $^{2}$ \& E. Bhero ${ }^{3}$
}

\section{ARTICLE INFO}

\section{Article details}

Presented at the 27th annual

conference of the Southern African

Institute for Industrial Engineering

(SAIIE), held from 27-29 October 2016

at Stonehenge in Africa, North West,

South Africa

Available online

11 Nov 2016

Contact details

Corresponding author

alwyn.hoffman@nwu.ac.za

Author affiliations

1 School of Electrical, Electronic and Computer Engineering, NorthWest University, Potchefstroom, South Africa

2 School of Economics, Faculty of Economic and Management Sciences, North-West University, Potchefstroom, South Africa

3 Discipline of Electrical, Electronic and Computer Engineering, School of Engineering, University of KwaZulu Natal, Durban, South Africa

DOI

http://dx.doi.org/10.7166/27-3-1659

\section{ABSTRACT}

Southern Africa critically depends on increased exports to enable economic growth and job creation. Logistical inefficiencies, however, are hampering exports, with cross-border freight delays a key contributor that adds cost and unpredictability to the supply chain, making South Africa an unattractive participant in global just-in-time value chains. The detention of cargo consignments at border posts is intended to reduce the risk of customs duties not being paid and to prevent the smuggling of illegal contraband. These risks must be weighed against the risk to trade caused by unpredictable time delays, and the resulting harmful impact on the economy. The increased use of ICT technologies has been proposed to enable a more attractive compromise between customs and trade risks. This study investigates the impact of the proposed new measures, including the use of technology, on the efficiency of cross-border freight movements. The research approach will combine the analysis of historical electronic transaction data exchanged between customs and consignors, with the simulation of different scenarios for the ICT support of customs processes. The expected impact of the proposed measures on exports within and from the SADC region, and the direct impact on corridor users, are estimated and compared against the estimated cost of the proposed measures. It is shown that implementing the proposed improvements should represent an attractive investment for the regional economy.

\section{OPSOMMING}

Suider-Afrika is krities afhanklik van verhoogde uitvoer om ekonomiese groei te bevorder. Logistieke tekortkominge beperk uitvoer, en oorgrens vertragings is 'n sleutelfaktor wat koste verhoog en onsekerheid veroorsaak in die lewering van uitvoergoedere. Dit lei daartoe dat Suid Afrika nie 'n aantreklike deelnemer is in globale net-betyds voorsieningskettings. Die risiko verbonde aan die nie-betaling van doeanebelastings moet opgeweeg word teen die ekonomiese koste veroorsaak deur huidige doeanepraktyke. Die voortel is dat ' $n$ uitbreiding in die inligting en kommunikasie tegnologieë ' $n$ meer voordelige kompromie mag inhou. Hierdie studie ondersoek die impak van die nuwe voorstelle en stel nuwe maatreëls voor om die effektiwiteit van die beweging van goedere oor landsgrense te verhoog. Die verwagte impak van die voorgestelde maatreëls op uitvoere vanuit die Suider-Afrikaanse Ontwikkelingsgemeenskap (SADC), sowel as die impak op korridorgebruikers, word kwantitatief bepaal en opgeweeg teen die verwagte koste van implementering.

The global economy is rapidly evolving with increased trade in goods, both intermediate and final, and services that add value. This drive for competitiveness is forcing countries to focus on specific 
levels in the value chain, finding trading partners across the globe rather than interacting mainly with suppliers and customers within their own jurisdictions. For this reason, successful economies must find ways to remove obstacles to the free flow of goods across national borders, whether this be at sea ports, land-based ports, or airports.

The countries of Southern Africa could benefit economically by viewing the region as a single entity or 'factory', combining resources and spreading manufacturing across the region, rather than competing against each other. However, one of the crippling factors in establishing this 'factory Southern Africa' is delays at borders along key transport corridors in the region [24]. While the benefit of reduced trade costs, occasioned by a reduction in trade obstacles, is generally accepted, experts disagree on the details [8]. What is rather consistent is that political will is indispensable. However, countries show a general reluctance to follow through on trade agreements; and this has an adverse effect on any cross-border initiative [5]. Even shared national borders do not guarantee trade integration if trade facilitation measures are incompatible [14].

Trade obstacles at border posts not only have a distinct financial impact on traders, but also cause welfare losses to entire economies of the affected countries. Trade obstacles can be removed or reduced by active trade facilitation initiatives.

The single biggest cause of long border delays in southern Africa is the compliance enforced by customs agencies on traders taking goods across borders, to collect customs duties and prevent illegal contraband smuggling. The legacy approach to ensuring compliance is to apply many intrusive inspections. In the case of border posts that must process high traffic levels, this can lead to excessive delays, resulting in the disruption of trade flows [24].

There are many reasons why intrusive inspections are so rampant in Africa and other developing regions. Numerous customs authorities in Africa rely on the use of ASYCUDA (Automated System for Customs Data), as it is sponsored by the United Nations; the early versions of ASYCUDA still being used in some countries operated as a closed system, and did not allow customs authorities to improve the risk management of their systems by using available data to assess customs risks. These systems were mostly limited to combining simple selection criteria such as lists of importers, the origin of goods, the applicable tax regime, etc. [15]. A second contributing factor is the use of less-developed risk management systems that employ simple criteria to select and blacklist exporters, importers, or goods. Thirdly, within these developing economies there is a dire need to maximise revenue through tax collection. Fourthly, general moral hazards are associated, not only with the traders, but even more so with customs officials who exploit the lack of transparency and proper governance to manipulate the system for personal financial gain.

The above background is the motivation for a study of possible interventions to reduce the negative impact of cross-border delays on the free flow of trade goods. As many independent stakeholders are involved in a typical border crossing, it is not a trivial matter to change the status quo; many of these stakeholders and the human operators who represent them in processing cross-border freight have conflicting - and sometimes hidden - agendas that create significant resistance to change. It is obvious, therefore, that a very strong economic argument will be required to overcome this resistance and to generate the required political will among governmental decision-makers to implement a new approach to handling cross-border trade.

The purpose of this paper is to quantify the impact of specific interventions on the operational efficiency of cross-border operations, and then to translate these operational improvements into expected benefits for the regional economy. We study the expected impact of such interventions both from the perspective of the export industry in general, and from the perspective of specific corridor users. The rest of the paper is structured as follows: Section 2 provides a literature overview of previous studies in the field. Based on the current literature, we motivate the problem statement and define the methodology to be applied in Section 0. In Section Error! Reference source not found. we propose specific interventions that could reduce such delays. In Section 5 we quantify the expected operational improvements resulting from the identified interventions, and translate these into expected economic benefits in Section 6. We conclude in Section 7 with our findings and recommendations and an overview of future work. 
In general, the economic literature accentuates the importance of upgrading trade facilitation initiatives in Africa, especially through customs reforms, as African countries lag far behind in terms of global standards. Preliminary calculations at the Beitbridge border post indicate that the cost implications of customs delays might be significantly higher than the global average, and could be one of the reasons why Southern Africa is one of the most expensive regions from which to export products. Given the existing literature on economic growth, global trade, and the impact of trade facilitation on both, it is evident that additional research is needed on trade barriers in Southern Africa.

In a recent study, Hoekman [9] observes the differences in definitions of the term 'trade facilitation' by various organisations. He finds that while the World Trade Organization (WTO) regards trade facilitation as the reform of border management processes, the Asia-Pacific Economic Cooperation (APEC) extends the definition to include policies affecting transport. The International Finance Corporation goes even further, including programmes that affect trade finance.

Not only is trade facilitation a broad field of study, it is also multidisciplinary in nature, including political, economic, business, administrative, technical, technological, financial, and legal elements [14]. It is generally accepted that a decline in trade costs will increase trade performance. However, achieving such reductions is complex, and some limitations, such as being a landlocked country, are impossible to change [9]. Nevertheless, a large share of trade costs is affected by administrative practices and, as a result, the greatest focus has recently been placed on it [9]. It has been pointed out that customs procedures are exceptionally slow in Africa, and customs procedures have been highlighted as a key priority on the continent [23]. For instance, due to risk assessment policy, 70 per cent of containers are opened and inspected in Africa, in contrast with only five per cent in the Organisation for Economic Cooperation and Development (OECD) countries [28].

Although sufficient and competitive infrastructure services such as transportation and telecommunication are essential for the development of global value chains, it is also deeply influenced by the efficiency of border processes and customs practices [21]. The quick movement of goods across borders was, in fact, the reason and basis for trade facilitation talks that started in 1996 at the World Trade Organization (WTO). Negotiations eventually concluded in December 2013, and the Trade Facilitation Agreement (TFA) was adopted. The aim of this agreement is to provide a general framework for addressing non-tariff barriers. Member countries are currently in the process of ratifying it, and the agreement will come into force once a two-thirds threshold has been reached. If it is taken into consideration that the full implementation of the TFA is calculated to reduce the cost of trade by around 15 per cent [16], the benefit to Africa is clear.

Research done on trade costs by Arvis [1] underlines continuous trade obstacles in developing countries and particularly in sub-Saharan Africa. The high costs associated with the movement of goods across Africa are undeniably one of the major contributing factors to the continent's poor trade performance [17]. Trade expansion often focuses more on growing and diversifying exports, while the importance of competitively-priced imported inputs and intermediates is overlooked [24]. Empirical evidence suggests that costs associated with customs procedures are 30 per cent higher, and document preparation takes 25 per cent longer, in Africa than the global average [23].

The SADC Protocol on Trade came into force more than 15 years ago with the objective of removing trade barriers, increasing investment and, as a result of increased trade between members, improving development. Trade liberalisation and the free movement of people and goods through the region are therefore SADC's two key goals [18]. Despite these goals, the SADC region is an excellent example of trade barriers blocking cross-border linkages within a region [28] and restricting the region to operating as one functional factory. Despite ample opportunity for production networks to develop around the region with South Africa as a regional powerhouse, very few global value chains have been established to date [28].

Table 1 indicates that only 20 per cent of trade in the region is internal. The other 80 per cent therefore consists of trade with other regions, such as the EU and the US. Most Southern African economies also have a narrow range of exports - mainly natural resources and commodities [24]. On-going decline in commodity prices signifies vulnerability, and not many economies have 
succeeded in sustaining increased exports without diversifying the export base to include manufacturing [24].

Table 1: SADC intra-regional trade 2004 - 2013

Total world exports Total SADC exports SADC-SADC exports Intra-SADC exports

\begin{tabular}{lllll} 
& US\$ (million) & US\$ (million) & US\$ (million) & $\%$ \\
\hline 2004 & $9,086,814$ & 60,976 & 9,163 & 15 \\
2005 & $10,342,461$ & 68,517 & 9,989 & 15 \\
2006 & $11,952,387$ & 84,394 & 14,580 & 17 \\
2007 & $13,772,780$ & 135,075 & 16,504 & 12 \\
2008 & $15,972,312$ & 173,257 & 19,431 & 11 \\
2009 & $12,314,697$ & 122,582 & 17,204 & 14 \\
2010 & $15,057,106$ & 173,346 & 33,275 & 19 \\
2011 & $18,066,515$ & 220,920 & 38,425 & 17 \\
2012 & $18,202,309$ & 221,100 & 41,594 & 19 \\
2013 & $18,684,466$ & 218,622 & 43,261 & 20 \\
\hline Data from database: ITC Trademap [12]
\end{tabular}

It takes the region on average 28.3 days to export a product, almost 17 days longer than in the European Union (EU) [27], and a far cry from the best global performers, who require only 6.5 days to export, and four to import, a container [27]. Various factors play a role in firms' total cost. While delivery times and transport costs are just two of them, some countries have been able to reduce trade costs through implementing trade facilitation measures [24]. Extensive trade facilitation initiatives are currently underway in the East African Community (EAC), whereas very little is taking place in the Southern African context.

Zimbabwe is a landlocked country providing essential trade links within Southern Africa along the north-south corridor, with many of the products moving from South Africa through Zimbabwe to other countries in the region. Beitbridge is the only border post connecting Zimbabwe with South Africa. More than 400 trucks cross the border daily, making it one of the busiest border posts in Southern Africa [20]. Smooth and quick operations are essential, given the importance of this border post; but the opposite is true: crossing times of a week, and sometimes longer, are frequently reported [20].

Recently-measured cross-border delays (as shown in Table 2 below) indicate that the average delay figures for those border posts that carry the most traffic - typically those along the north-south corridor, including Beitbridge (South Africa to Zimbabwe), Chirundu (Zimbabwe to Zambia), and Kasumbalesa (Zambia to the Democratic Republic of the Congo) - are between 24 and 46 hours. This is in line with figures mentioned in previous studies.

Table 2: Cross-border delay times for SADC border posts

\begin{tabular}{|c|c|}
\hline Border post & Ave delay (hrs) \\
\hline Beitbridge & 24.5 \\
\hline Chirundu & 24.1 \\
\hline Kasumbalesa & 39.4 \\
\hline Kazungula & 42.3 \\
\hline Nakonde & 46.0 \\
\hline
\end{tabular}

One of the biggest causes of delays is customs inspections at these border posts. The Revised Kyoto Convention (RKC) is a trade facilitation convention that was initiated by the World Customs Organization (WCO). The RKC recommended limiting intrusive customs inspections; this has increasingly caused governments in developed countries to move away from intrusive customs inspections [6] in favour of non-intrusive inspections. On the other hand, Buyonge and Kireeva [4] and Laporte [15] argue that, in African and other developing regions, intrusive inspections are still rampant, and that these cause long delays through inefficiencies observed at the border posts of these countries. Buyonge and Kireeva [4] attribute this state of affairs to a number of factors, 
including poor relations between customs and business, insufficient supporting state infrastructure, multiple and different inspection agencies, and general corruption within customs authorities.

Buyonge and Kireeva [4] argue that if Africa is to develop faster economically, it has to reduce trade transaction costs substantially, among other measures. The high trade transaction costs are caused by a number of factors, including delays associated with customs processes. Buyonge and Kireeva [4] are of the view that customs reform and modernisation initiatives are indispensable elements for trade facilitation. On the other hand, the reality is that in Africa the majority of countries are still dependent on revenue from customs operations [10]. This means that extensive and intrusive inspections are carried out to maximise the revenue from payable tax and duties.

Studies show that time delays have a negative impact on exports [7]. Trade decreases at least one per cent on average for each day a product is delayed before delivery [7]. It is even worse for exports of perishable agricultural products, where a one-day delay reduces exports by six per cent [7]. Of equal importance are intermediate products (manufactured goods in a supply chain), representing more than half of the current global trade flow [22]. These products are, according to Hummels and Schaur [11], 60 per cent more time-sensitive than final goods. It has been observed, however, that faster customs clearance and document preparation alone might not be enough to provide adequate support for trade expansion, and that an all-inclusive approach is required where reliable delivery times, reduced transport costs, and more competitively-priced imported inputs are also addressed [24]. This draws attention to the significance of trade facilitation measures to enhance trade flow, and thus justifies an investigation into the impact of time barriers on regional trade.

Empirical evidence suggests that customs delays carry an average weighting of between 0.6 per cent and 2.1 per cent of traded cargo value [11]. However, at Beitbridge, the border post connecting Zimbabwe and South Africa, it takes three days on average just to cross the border. Rough calculations indicate a price increase in consumer goods of between 2.97 per cent and 13.90 per cent due to delays at this border post [20]. An analysis of the cost implications of border delays and the impact they have on trade in Southern Africa is thus imperative.

A prior study that is very relevant to this paper is the work that was done by Laporte [15]. He made reference to the Revised Kyoto Convention (RKC) and World Trade Organization (WTO) proposals on trade facilitation that discourage intrusive customs inspections. As a result, governments in the developed world are increasingly becoming involved in the various stages of the customs chain with the aid of data communication and risk estimation tools. Laporte argued that the focus has shifted significantly in the developed world to an a posteriori inspection. Laporte was able to show that, by using statistical risk profiling methods, it is possible to detect 96.6 per cent of declarations with infractions by inspecting only 20.6 per cent of the declarations. For developing countries, whose governments' aim is to maximise revenue through duty collections, it is suggested that they use these statistical risk profiling methods together with real-time monitoring techniques.

In another related work, Siror, Huanye and Dong [19] conducted a pilot project in Kenya. One of their objectives was to investigate how technology could be used to curb the unlawful discharge of goods earmarked for export or transit into the Kenyan market. They used a combination of technologies including a radio frequency identification (RFID) system and a global positioning system (GPS). The pilot project involved using RFID electronic seals to seal goods and truck container doors to prevent unauthorised tampering with the goods. The goods trucks were then tracked as they travelled from the point of origin to the port of exit. Along the route the trucks passed through a number of check points where the status of the electronic seals was checked for integrity with electronic readers. Also, to ensure that the goods trucks did not deviate from the set route between the source and the port of exit, their movement was tracked using GPS technology. The deviation of goods trucks from the set route is usually linked to malpractices such as removal from, or addition of illegal goods to, the truck-load. In the pilot project, 284 trips were analysed. Siror et al. [19] reported that 74 errors detected in the system were associated with a combination of GPS and RFID seal errors. On this aspect, the system had a success rate of 74 per cent. Siror et al. [19] further reported that the transit time from different places of origin to the port of exit decreased from a range of 33 to 100 hours, to a range of 20 to 80 hours. They also found that truck and cargo owners realised an increased efficiency of about 45 per cent in savings on turn-around times. 
From the literature study it is clear that economic growth in sub-Saharan Africa is restricted by obstacles to free trade, and that border crossings represent an important element that justifies efforts towards improvement. Current cross-border processes are largely based on a legacy from an era when volumes to be handled were much lower, and where manual interventions were the order of the day. At the same time, it is clear that improved processes enabled by technology, as employed in most developed economies, can go a long way towards eliminating most of these obstacles.

The primary purpose of our current research work is to generate scientific evidence of the benefits to the regional economy into modernising the current approach to handling cross-border trade. A second objective is to demonstrate that technically-viable practical measures can have a significant impact on cross-border delays. Thirdly, we quantify the expected impact of the proposed measures, and perform a cost-benefit analysis to determine which of the proposed measures can be justified, based on economic considerations. Lastly, we demonstrate that the proposed changes to the handling of cross-border trade will not create new conflicts between the objectives of customs and trade, but that they will specifically facilitate the reconciliation of these potentially conflicting interests. The overall objective of this article is to provide evidence that the objectives of customs (improved compliance) and of trade (improved cargo flow efficiencies) can be simultaneously achieved through an improved set of measures (supported by technology), and that the economic benefits resulting from these improvements will far outweigh the foreseeable costs.

In order to achieve our research objectives we will complete the following steps:

1. The estimated economic impact of current border crossing delays will be quantified, both from the perspective of the overall regional economy, and from the perspective of road transport operators who convey goods across national borders in sub-Saharan Africa.

2. Specific new interventions will be identified and their expected impact on cross-border trade will be estimated; the measures that will be considered include improved customs risk profiling based on data analytics, and the use of telematics to create a richer data set to support more effective customs process flows.

3. The expected impact of these interventions on the regional economy is estimated. We limit our study to the impact of reduced cross-border delays, as this is the easiest factor to quantify from among a set of trade facilitation improvements.

4. We also limit our measurement of regional economic impact to the impact on exports, partly because this is the economic activity that is most directly impacted by cross-border cargo movements, and partly because the relationship between exports and cross-border delays has been quantified through earlier studies [11].

5. We then proceed to perform a cost-benefit analysis that compares the direct economic benefits to corridor users against the estimated costs of the proposed interventions.

6. Based on the results from the above analyses, we will derive conclusions and make practical recommendations for improving the status quo.

\section{PROPOSED INTERVENTIONS FOR IMPROVING CROSS-BORDER TRADE FLOWS}

Proposed new interventions for improving cross-border efficiencies are discussed in two categories, as previously identified: the first, which can be based on existing data and that should therefore be relatively easy to implement, is the use of analytical data-based models for the statistical profiling of customs risks. The second category of measures involves the use of telematics technology to collect additional data reflecting the physical movements of cargo and cargo vehicles from origin to the point of clearance. As this will involve either the deployment of new technology or integration between customs systems and existing systems operated by corridor users, this will require a much bigger effort to implement. All proposed measures are, however, based on proven technology that has been successfully deployed in other application domains.

\subsection{The use of data analytics for statistical profiling of customs risk}

The measures proposed in this section are aimed at using data that is already available to customs more effectively, and are based on the work that was done by Laporte [15]. Laporte suggested an approach that is score-based, where the score for each declaration is computed using appropriate 
statistical methods applied to data contained in the declaration. He tested his proposed riskprofiling system using two methods:

i. The first method was based on simple methods for score calculation. Under this method, he compared simple averages, weighted averages, and the maximum values for the frequency of infringements for the various selected criteria.

ii. The second method was based on econometric models for score calculation. Under this method, he compared a simple linear probability model with the probit and logit models.

Laporte's method for a customs risk management scoring system can be summarised as follows:

- $\quad$ Six criteria are used in risk profiling. These include the health and safety (HS) aspect of the goods, their origin, provenance, freight agents, importer/exporter, and the applicable customs regime.

- $\quad$ Risk profiles are based on the historical frequency of infringements for declarations with a value corresponding to the value for that criterion for the current declaration.

- $\quad$ Binary numbers are used to represent risk level. A ' 1 ' indicates a high risk of infringement and a ' 0 ' indicates no risk or a low risk of infringement.

- Using statistical methods, the probability of an infringement occurring is computed from the following econometric equation:

$$
\operatorname{Pr}(\text { Inf. })=\alpha+\beta_{1} \mathrm{fq}_{- \text {criteria }_{1 \mathrm{ij}}}+\beta_{2} \mathrm{fq}_{-\mathrm{criteria}_{\mathrm{ij}}}+\cdots+\beta_{\mathrm{N}} \mathrm{fq}_{-\mathrm{criteria}_{\mathrm{ij}}}+\varepsilon_{\mathrm{ij}}
$$

where $\operatorname{Pr}$ is the probability of infringement for a declaration $\mathrm{ij}$, and $\mathrm{fq}_{-\mathrm{ij}}$ is the frequency of customs infringement for the criterion over a specified period. The term $\varepsilon_{i j}$ is the error term, and $a$ and $B$ are the model parameters that must be determined.

- $\quad$ Risk scores are categorised to facilitate decision-making when targeting various goods with different risk scores. For example, categories for the risk score can be from 0.01 to 0.02 , from 0.02 to 0.04 , and so forth, up to a value of 1 .

- An intrusive customs inspection will be triggered only if the score for the respective consignment exceeds a set threshold level; the level at which the threshold is set will represent a compromise between the risk of customs non-compliance and the impact on trade flows.

\subsection{Using telematics to create a richer data set for customs risk profiling}

The measures described in the section are aimed at expanding the data set available to customs, on the basis of which they can generate a risk outcome for each consignment. To determine which data to add through telematics, it is necessary to identify the primary contributors to long delays. Based on recent studies performed in the cross-border field [14], it is clear that human processes are the primary culprits. The current nature of the process required to clear a consignment from customs involves, among other things, the following:

- While declarations to customs can be made electronically before a consignment reaches the border (at least in some countries), it is still a requirement that physical paperwork be submitted to customs at the border. In the process of passing documents from the truck driver to a clearing agent and then via a 'runner' to customs and back again, some of the paperwork is often mislaid, resulting in delays as new documents are generated.

- The fact that a human-controlled clearing process is required means that customs officials have the opportunity to manipulate the clearance process for personal gain. Studies have shown that, in some cases, pre-declaring documents, instead of expediting the process, tended to slow it down [23]. The probable reason is that it allows unscrupulous customs officials more time to target consignments for deliberate delays in order to extort bribes.

The obvious solution to the problem is to automate the process of clearing consignments as far as is practically possible. In order to do this without increasing the risk of leakage of non-compliant goods across borders, it will be necessary to rely to a larger extent on technology to complement human processes. Technology can be employed in several ways to provide customs authorities with much more detailed information on the physical status of freight consignments arriving at a border, allowing much more accurate discrimination between those consignments with a high likelihood of being compliant and the potentially suspicious ones that justify inspections. Technology can also be 
used to police processes controlled by human operators to ensure that the appropriate steps are taken and that an audit trail exists of all actions taken by officials.

The improved cross-border management concept that is proposed in this paper consists of the following elements:

1. A certification system for freight forwarders and transporters, combined with incentives for self-regulation: The majority of participants prefer to be fully compliant as long as they will receive benefits in the form of faster processing through borders. A certification system will only work effectively, however, if compliant consignments of certified transporters can be accurately distinguished from potentially non-compliant consignments of non-certified transporters. Telematics can contribute towards this objective, as described below.

2. Automated channelling of freight traffic at border posts: Ideally the system must automatically separate compliant from non-compliant traffic upstream from where trucks are finally cleared for crossing, so that non-compliant traffic will have minimal impact on the flow of compliant traffic, as described in Figure 1 below. This will effectively enable the implementation of a Green Lane / Red Lane system.

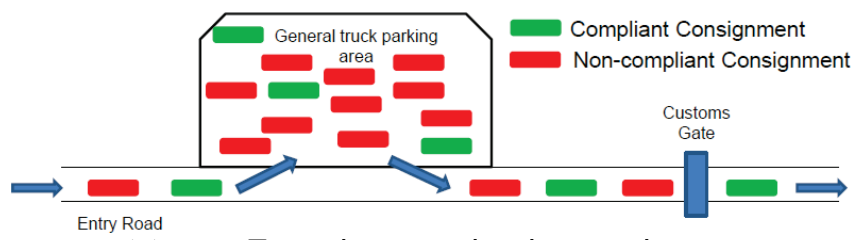

(a) Typical current border post lay-out

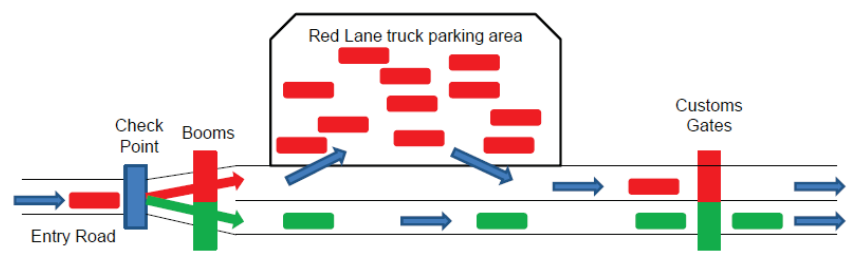

(b) Green Lane / Red Lane border post lay-out

Figure1: Proposed change in traffic flow management at border posts

3. Marking of documents: Documents handed in for customs inspections must be marked with a machine-readable code to enable automatic detection of paperwork when submitted and handled as part of the clearance process. This will serve as a performance measurement tool; it can also be used to verify that the contents were not manipulated; and it will accurately link documents to related vehicles.

4. The marking and automated detection of freight vehicles: This will enable accurate and automated separation of certified and non-certified vehicles; secondly, it will verify that all consignments for which paperwork was cleared actually crosses the border, and that only those vehicles for which the paperwork has been cleared can move through a customs gate.

5. The use of electronic seals on cargo containers: This will reduce the risk that cargo has been tampered with from the time it was initially sealed. The electronic seal can be automatically checked at specific points along major corridors (typically at weigh bridge stations) to provide regular feedback that the consignment is still intact. Using more sophisticated technology it will even be possible to provide continuous feedback about the current status of seals [13].

6. Providing customs authorities with detailed information on the movements of consignments from the time of dispatch until they reach the border: If a vehicle is dispatched by a certified participant in good standing and this vehicles reaches the border within standard travelling times, without any unexpected deviations from the designated route, without any unexpected changes in weight, and with the original cargo seals still intact, it could reasonably be assumed that such a vehicle represents minimal customs risk. By automatically presenting customs with such information on arrival at the border, it will be possible automatically to process and acquit those vehicles that are fully compliant based on the above set of measurements. This will allow the customs authority to focus its limited law enforcement capacity on the minority of consignments that are not fully compliant. 
7. Using handheld technology: Handheld computers can provide customs officials with real-time decision support while performing their inspection duties, while at the same time policing their actions to ensure that correct practices are applied to all consignments being inspected. This will prevent customs officials from delaying specific consignments without receiving corresponding instructions from the customs risk engine. It will also force officials to inspect cargo that has been selected by the risk engine, and to report on findings. While these measures may not prevent all misconduct by customs officials, it will at least make them aware of the fact that their actions are visible within the larger system and that they will be held accountable if found to be in collusion with truck drivers or syndicates.

\section{QUANTIFYING THE OPERATIONAL IMPACT OF PROPOSED IMPROVEMENTS}

The expected operational impact of the measures proposed above are now estimated, partly by analysing historical customs data where the outcomes of inspections were known, and partly be simulating modified processes that rely on telematics to automate the process.

\subsection{Customs risk profiling based on statistical models}

Using the customs risk profiling model described in Section 4.1, Laporte [15] was able to show that, by using statistical risk profiling methods, it is possible to detect 96.6 per cent of declarations with infractions by inspecting only 20.6 per cent of the declarations. It can therefore be argued that it should be possible to reduce the number of intrusive inspections by 80 per cent, while still correctly identifying the vast majority of consignments that represent an infringement.

Based on the literature study, the average border post delay for border posts carrying high traffic levels is about 36 hours. The expected improvement to cross-border delays from this intervention should therefore be about 29 hours; to be on the conservative side we can round the expected improvement in cross-border delays down to one day ( 24 hours).

\subsection{Enhancing efficiency based on telematics}

A simulation study was performed to quantify the expected impact of some of the proposed interventions identified in Section 4.2 above. The simulation model that was used is described in detail in Bhero, Hoffman, Lusanga, and de Corning [2]. In this section we summarise the primary results that were generated through that study. Only two of the potential measures discussed in Section 4.2 were included in this simulation study.

\section{A. Increasing customs processing capacity}

It was assumed that compliant consignors will declare the dispatch of trucks destined for a specific border, informing the customs authority at each border post about the expected arrival time. This will allow the customs authority to determine the expected cross-border traffic at any given time, allowing them to prepare sufficient processing capacity to match the traffic levels.

\section{B. Using RFID enabled Green Customs Lanes}

This scenario included separate Green and Red Lanes for compliant and non-compliant cargo. The proportion of compliant cargo was gradually increased and border transit times determined. Compliant cargo in the proposed system is processed through the Green Lane; thus, as the percentage of compliant consignments increases, the processing capacity of the green lanes is adversely affected. Therefore, cargo with shorter processing time is expected to experience additional queuing time.

Figure 2 shows the simulated results where the proportion of cargo that is compliant was gradually increased and border transit times determined. Exchange of information was also enabled to allow the customs risk engine and management system to estimate expected volumes of arrivals, and to allocate customs processing capacity accordingly. The simulation was performed for each of the following cargo types: All, Break Bulk, Consolidated, Refrigerated, and Tanker. This was done because historical statistics showed that different cargo types, on average, experience different delays. The figures for 0 per cent compliance correspond with the actual delays experienced on average by the different cargo types at the Beitbridge border post. It can be seen that, with increasing compliance levels, all cargo types processed through the Green Lane experience a steady decrease in transit time to a minimum of 4.83 hours as the percentage of compliant cargo increases. 


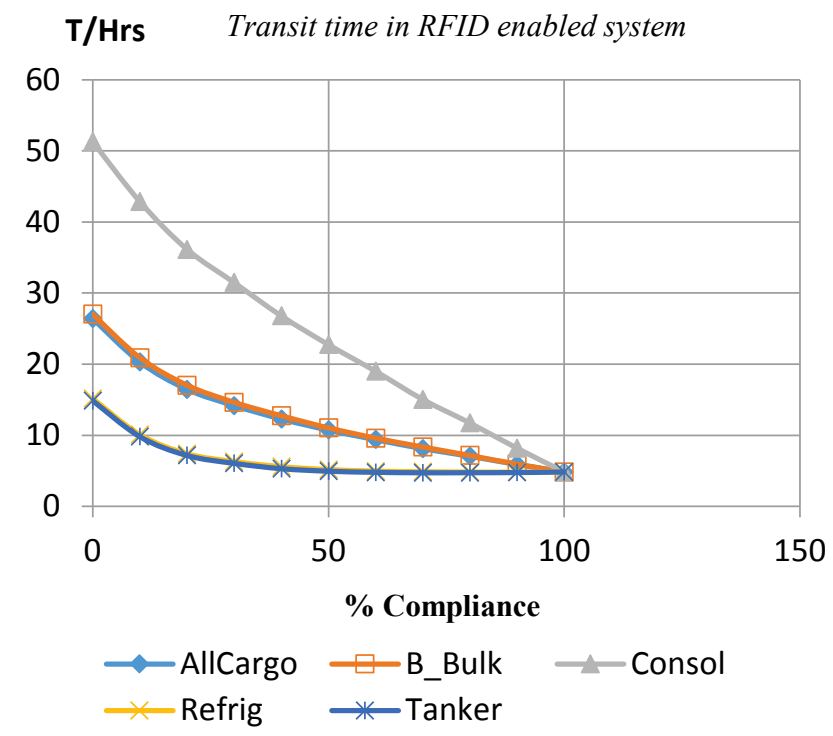

Figure 2: Transit times with dynamic scheduling of customs capacity

\section{QUANTIFYING THE ECONOMIC IMPACT OF PROPOSED IMPROVEMENTS}

Section 5 above provided convincing evidence of the potential improvement in operational efficiencies in cross-border processes, based on the proposed interventions. In order to create a convincing argument to justify a significant effort from the respective customs authorities to overhaul their current systems, it is necessary to translate these operational improvements into expected economic benefits to the region in general, and to corridor stakeholders in particular. In this section, we combine our results on expected operational improvements with the results of previous studies that quantified the impact of cross-border delays on export potential and on the cost-efficiency and profit potential of corridor users.

\subsection{Economic impact on the regional economy}

The approach that we take is as follows:

- We use the historical figures generated by Hummels [11] that estimate the impact of increased or reduced cross-border delays on exports to estimate by what percentage the various measures proposed in Section 4 might be expected to influence export figures.

- $\quad$ Publicly-available figures on the level of exports between different neighbouring countries within SADC are used to translate the expected percentages into monetary amounts; these figures can then be further translated into increased tax revenues and expected creation of employment.

The results from previous studies on the application of statistical profiling, as described in Section 4.1, provide evidence that more than 96 per cent of cross-border infractions can be detected by inspecting only 20 per cent of consignments that are currently subject to inspections. These studies were based on the use of currently-available declaration data only, and excluded any new interventions relying on telematics. We can therefore state with reasonable certainty that the volume of customs inspections can be reduced by 80 per cent or more if more advanced techniques were employed.

In Section 4.2 we demonstrated though a simulation study how telematics can be used to reduce cross-border delays by up to 90 per cent, even with the current level of physical inspections. Thus, by combining these two sets of results, we can claim that a system based on both telematics and data analytics should be able to reduce cross-border delays by 80 to 90 per cent while implementing stricter controls over potentially-suspicious consignments. The benefit generated for cross-border trade will therefore be achieved not at the cost of reduced customs compliance; if correctly 
implemented, it should be accompanied by improved compliance levels. Making a conservative estimate, we can state that the proposed interventions could, on average, reduce cross-border delays by about one day.

Table 1 shows that intra-SADC exports in 2013 exceeded US\$ 40 billion. Based on the estimates made by Hummels [11] and our own estimates of potential reduction in cross-border delays, we can estimate the potential improvement in export levels to be at least one per cent, amounting to more than US\$ 400 million per annum. We can also extrapolate these figures to SADC's exports to the rest of the world, which are about five times higher. The vast majority of SADC's exports move through sea ports, which are plagued by similar delays and inefficiencies to those of land-based border posts. If similar measures were applied to cargo movements through sea ports, the economic potential of the proposed interventions could be much larger.

\subsection{Economic impact on corridor users}

The economic impact of cross-border delays on corridor users was determined by translating border delays into reduced truck-use levels for a typical fleet that is used to transport cross-border cargo. Information was obtained from several commercial transporters about the actual income and cost figures applicable to typical road freight operations in African corridors. The availability of this data made it possible to estimate accurately the economic losses suffered by transport companies from increased round-trip times for trips to African destinations.

The costs associated with reduced use of trucks due to cross-border delays are calculated based on the set of values as described in Table 3 below; these values were obtained from the operations of a transporter doing trips between South Africa, Zambia, and the DRC [26]. Firstly, we calculate the economics associated with an average cross-border trip, including total cost, income generated, and profit. Using the average turnaround time we calculate the average monthly income, cost, and profit for one truck.

Table 3: Economics per trip

\begin{tabular}{|l|l|}
\hline Monthly interest rate & $1.0 \%$ \\
\hline No. of monthly installments & 120 \\
\hline Average cost of truck & $\$ 180000$ \\
\hline Monthly installment & $\$ 2582$ \\
\hline Average income per trip & $\$ 8000$ \\
\hline Average distance per trip $(\mathrm{km})$ & 4000 \\
\hline Average fuel consumption $(\mathrm{km} / \mathrm{l})$ & 1.5 \\
\hline Cost of fuel per litre & $\$ 1.40$ \\
\hline Average cost of fuel per trip & $\$ 3733$ \\
\hline Cost of driver per trip & $\$ 700$ \\
\hline Additional cross-border expenses per trip & $\$ 700$ \\
\hline Other costs per trip (tolls, etc.) & $\$ 180$ \\
\hline Total trip costs excluding financing of truck & $\$ 5313$ \\
\hline
\end{tabular}

The loss of income and profit per truck is then calculated by using the fraction of total trip time that is consumed by cross-border delays. Average waiting time at border crossings ( 39 hours) was calculated using studies that were conducted over several years, in each case involving the measurement of delay times for several hundred trucks over periods of several months. By calculating the total average border crossing times for the entire trip and subtracting this from the average trip duration, we obtain the trip duration for zero border crossing delays. Using this figure, it is possible to calculate the monthly profits than can be generated per truck if border crossing delays were reduced to two hours, as shown in Table 4.

In order to determine the overall impact on the regional economy, we calculate the difference in profits that can be generated by a fleet of trucks with a reduced round-trip delay. We make the conservative assumption that the total demand for road freight transport will not increase when cross-border delays are reduced, but that the need could be met by using a smaller fleet of trucks. This will result in two benefits: 
Table 4: Monthly profits per truck

\begin{tabular}{|l|l|l|}
\cline { 2 - 3 } \multicolumn{1}{c|}{} & $\begin{array}{l}\text { Current } \\
\text { scenario }\end{array}$ & $\begin{array}{l}\text { Improved } \\
\text { scenario }\end{array}$ \\
\hline Average speed of travel $(\mathrm{km} / \mathrm{h})$ & 70 & 70 \\
\hline Number of hours' driving per day & 8 & 8 \\
\hline Number of days driving per trip & 7.1 & 7.1 \\
\hline $\begin{array}{l}\text { Number of border crossings per } \\
\text { trip }\end{array}$ & 4 & 4 \\
\hline $\begin{array}{l}\text { Average cross-border delay } \\
\text { (days) }\end{array}$ & 1.63 & 0.08 \\
\hline $\begin{array}{l}\text { Total border delay per trip } \\
\text { (days) }\end{array}$ & 6.50 & 0.33 \\
\hline Average trip duration (days) & 13.6 & 7.5 \\
\hline Number of trips per month & 2.0 & 4.0 \\
\hline Income per month & $\$ 15690$ & $\$ 31809$ \\
\hline Costs per month & $\$ 13003$ & $\$ 23709$ \\
\hline Profits per month & $\$ 2687$ & $\$ 8100$ \\
\hline
\end{tabular}

- There will be a saving in the total required investment in the regional truck fleet from US\$ 1.08 billion to US\$ 0.53 billion, as shown in Table 5 . Assuming an annual interest rate of 12 per cent for lease purchases, this positive impact on financing cost amounts to almost US\$ 66 million per annum.

- $\quad$ As the smaller fleet will be operated more profitably, there will still be an increase in total annual profits: the increased annual profits are calculated at just more than US\$ 94 million.

Table 5: Comparison: Current vs improved scenario

\begin{tabular}{|l|l|l|}
\hline & $\begin{array}{l}\text { Current } \\
\text { scenario }\end{array}$ & $\begin{array}{l}\text { Improved } \\
\text { scenario }\end{array}$ \\
\hline Number of trucks & 6000 & 2960 \\
\hline Investment in trucks & $\$ 1080000000$ & $\$ 532713195$ \\
\hline Annual installments & $\$ 129600000$ & $\$ 63925583$ \\
\hline Total profits per month & $\$ 16119991$ & $\$ 23971967$ \\
\hline Increase in annual profits & - & $\$ 94223708$ \\
\hline
\end{tabular}

It can be seen that the annual benefit to the transport industry of improved cross-border operations, based just on improved truck use, could amount to about US\$160 million. This figure is comparable in size with the expected positive impact on exports, as determined in the previous section.

In order to determine whether the cost benefit will be positive, it is necessary to estimate the expected costs of deploying the proposed system. Firstly, the cost of capital deployment at border posts is estimated. The figures in Table 6 are used as the basis for the cost estimation. Only a summary of costs is shown; the rest are found in Bowland [3]. In order to cover the major routes used by the roughly 6,000 trucks doing regular trips from South Africa into the rest of Southern Africa, it will be necessary to equip around 20 border posts [23]. The capital outlay will include civil works to implement screener lanes, installing RFID readers in weigh-in-motion (WIM) and customs lanes, handheld terminals and desktop scanners used by officials, and customised software and integration with field equipment.

The number of independent consignors who would be interested in certification is estimated at a maximum of 500 (according to SACBTA industry figure, only about 160 transporters of significant size operate between South Africa and neighbouring countries). The average cost per consignor comes to about US\$80,000, with a total industry capital outlay of US\$ 40 million. The capital outlay for all stakeholders together amounts to around US\$ 58 million. 
Table 6: Capital outlay for system deployment

\begin{tabular}{|l|l|}
\hline Cost of capital outlay at weigh bridges: & \\
\hline Number of weigh bridges & 48 \\
\hline Number of lanes per weigh bridge & 2 \\
\hline Cost per equipped lane & $\$ 30000$ \\
\hline Total capital outlay per weigh bridge & $\$ 221000$ \\
\hline Total cost for all weigh bridges & $\$ 10608000$ \\
\hline Cost of capital outlay at border posts: & \\
\hline Number of border posts & 20 \\
\hline Number of customs lanes per border post & 4 \\
\hline Cost per equipped customs lane & $\$ 30000$ \\
\hline Total capital outlay per border post & $\$ 307300$ \\
\hline Total cost for all border posts & $\$ 7406000$ \\
\hline Cost of capital outlay at consignors: & \\
\hline Number of certified consignors & 500 \\
\hline Number of trucks & 6000 \\
\hline Total capital outlay per consignor & $\$ 80324$ \\
\hline Total capital outlay for all consignors & $\$ 40162000$ \\
\hline
\end{tabular}

If the above costs are compared with the estimated benefits, it can be seen that, using a conservative estimate for the expected benefits (i.e., assuming no increase in traffic but assuming improved profitability per trip), the proposed system should pay for itself in less than 12 months. This does not even consider the reduced long-term investment in trucks or the positive spin-offs for the regional economy resulting from a more efficient transport sector. Based on the assumptions that the annual maintenance and operational costs are 25 per cent of the initial capital outlay, and that the system has a life expectancy of 10 years, the expected internal rate of return (IRR) amounts to 137 per cent.

\section{CONCLUSION AND RECOMMENDATIONS}

From our literature study, it is clear that trade facilitation - and, more specifically, the streamlining of customs processes to reduce cross-border delays - can have a significant impact on exports and economic growth in the SADC region. In this paper we proposed specific measures to reduce the impact of customs processes on cross-border delays, and estimated the quantified impact of these measures. The proposed measures are partly based on the use of analytics with historical customs statistics in order to profile the risk of declaration more accurately, and partly on the use of telematics technology to enable more efficient customs process flows, including the implementation of a Green Lane / Red Lane system.

Our results show that cross-border delays can on average be reduced by at least one day, resulting in an expected increase in annual export within SADC of about US\$ 400 million, with a potential increase in exports to the rest of the world of US\$ 2 billion. The direct benefit to corridor users is estimated at US\$ 160 million, based on the increased usage levels of their trucks. The total cost to implement these measures is estimated at less than US\$ 60 million, providing a fast payback to the regional economy.

Future work will involve a more detail study of the expected impact of various trade facilitation measures, using GTAP models to simulate the response of the regional economy to such measures. The simulation study on the impact of telematics on cross-border delays will also be expanded to include all of the proposed measures described in this paper.

\section{REFERENCES}

[1] Arvis, J.D. 2013. Trade costs in the developing world: 1995-2010. Washington, DC: World Bank.

[2] Bhero, E., Hoffman, A., Lusanga, K. \& de Corning, A. 2015. Impact of a radio-frequency identification system and information interchange on clearance processes for cargo at border posts. Journal of Transport and Supply Chain Management, 9(1), pp. 1-14. 
[3] Bowland, C.0. 2012. Implementing development corridors: Lessons from the Maputo corridor. Johannesburg: South African Institute of International Affairs.

[4] Buyonge, C. \& Kireeva, I. 2008. Trade facilitation in Africa: Challenges and possible solutions. World Customs Journal, 2(1), pp. 41-54.

[5] Byiers, B.V. 2014. What drives regional economic integration? Lessons from the Maputo development corridor and the North-South corridor. Maastricht: European Centre for Development Policy Management.

[6] De Wulf, L. \& Sokol, J.B. 2004. Customs modernization initiatives: Case studies. Washington, DC: World Bank. Retrieved October 6, 2015, from https: / /openknowledge. worldbank.org/bitstream/handle/10986/14911/301120PAPEROCustoms0case0stu dies.pdf?sequence $=1$

[7] Djankov, S.F. 2006. Trading on time. Washington, DC: World Bank.

[8] Duval, Y. 2006. Cost and benefits of implementing trade facilitation measures under negotiations at the WTO: An exploratory survey. Asia-Pacific Research and Training Network on Trade.

[9] Hoekman, B. 2014. The Bali Trade Facilitation Agreement and rulemaking in the WTO: Milestone, mistake or mirage? London: Centre for Economic Policy Research.

[10] Hoffman, A.J. 2010. The use of technology for trade corridor management in Africa. NEPAD Transport Summit. Sandton.

[11] Hummels, D.\& Schaur, G. 2013. Time as a trade barrier, American Economic Review, pp. 2935-2959.

[12] ITC. 2016. Trademap database. Retrieved from www.trademap.org.

[13] Johnson, R.G. 2006. Tamper-indicating seals: Practices, problems, and standards. Los Alamos: Los Alamos National Laboratory.

[14] Jordaan, A.C. 2014. The impact of trade facilitation factors on South Africa's exports to a selection of African countries, Development Southern Africa, 31(4), pp. 591-605.

[15] Laporte, B. 2011. Risk management systems: Using data mining in developing countries' customs administration. World Customs Journal, 5(1), pp. 17-28.

[16] Organisation for Economic Co-operation and Development. 2014. Trade facilitation indicators: an overview of available tools. http://www.oecd.org/tad/facilitation/tfi-overview-availabletools-2014.pdf Date of access: 18 February 2015.

[17] Portugal-Perez, A.W. 2008. Trade costs in Africa: Barriers and opportunities for reform. (Policy research working paper 4619). Washington, DC: World Bank.

[18] Poverello, M. 2015. An interesting take on SADC developments and the lack of progress. Retrieved November 13, 2015 from http: / /mpoverello.com/2015/10/20/ an-interesting-take-on-sadc-developmentsand-the-lack-of-progress/

[19] Siror, J., Huanye, S. \& Dong, W. 2010. Impact of RFID technology on tracking of export goods in Kenya, Journal of Convergence Information Technology, 5(9), pp. 1532-1539.

[20] South African Institute of International Affairs. 2014. Regional business barriers: Unlocking economic potential in southern Africa. Johannesburg: South African Institute of International Affairs.

[21] Taglioni, D.W. 2014. Making global value chains work for development. Washington, DC: World Bank.

[22] United Nations. 2015. Key statistics and trends in international trade, 2014. United Nations Conference on Trade and Development. New York.

[23] United Nations Economic Commission for Africa. 2013. Trade facilitation from an African perspective. Addis Ababa: United Nations Economic Commission for Africa.

[24] USAID. 2015. LEAP-II Trade Intervention Agenda SA Final Report. Washington, DC: The United States Agency for International Development.

[25] Wiggill, T. 2015. Added value. Retrieved November 28, 2015 from http: //www.transportworldafrica.co.za/2015/10/29/added-value/.

[26] World Bank. 2005. Doing business in 2006. Washington, DC: World Bank.

[27] World Bank. 2012. De-fragmenting Africa: Deepening regional trade integration in goods and services. Washington, DC: World Bank.

[28] World Bank. 2015. Doing business 2015: Southern African Development Community (SADC). Washington, DC: World Bank. 